\title{
Quantitative Analysis of Oxygen Gas Exhausted from Anode through In Situ Measurement during Electrolytic Reduction
}

\author{
Eun-Young Choi, Jeong Lee, Dong Hyun Heo, and Jin-Mok Hur \\ Korea Atomic Energy Research Institute, Daedeok-daero 989-111, Yuseong-gu, Daejeon 34057, Republic of Korea \\ Correspondence should be addressed to Eun-Young Choi; winikjist@naver.com
}

Received 4 April 2017; Accepted 13 July 2017; Published 21 August 2017

Academic Editor: Keith E. Holbert

Copyright (C) 2017 Eun-Young Choi et al. This is an open access article distributed under the Creative Commons Attribution License, which permits unrestricted use, distribution, and reproduction in any medium, provided the original work is properly cited.

\begin{abstract}
Quantitative analysis by in situ measurement of oxygen gas evolved from an anode was employed to monitor the progress of electrolytic reduction of simulated oxide fuel in a molten $\mathrm{Li}_{2} \mathrm{O}-\mathrm{LiCl}$ salt. The electrolytic reduction of $0.6 \mathrm{~kg}$ of simulated oxide fuel was performed in $5 \mathrm{~kg}$ of $1.5 \mathrm{wt} . \% \mathrm{Li}_{2} \mathrm{O}-\mathrm{LiCl}$ molten salt at $650^{\circ} \mathrm{C}$. Porous cylindrical pellets of simulated oxide fuel were used as the cathode by loading a stainless steel wire mesh cathode basket. A platinum plate was employed as the anode. The oxygen gas evolved from the anode was exhausted to the instrumentation for in situ measurement during electrolytic reduction. The instrumentation consisted of a mass flow controller, pump, wet gas meter, and oxygen gas sensor. The oxygen gas was successfully measured using the instrumentation in real time. The measured volume of the oxygen gas was comparable to the theoretically calculated volume generated by the charge applied to the simulated oxide fuel.
\end{abstract}

\section{Introduction}

Electrolytic reduction (also called oxide reduction or OR) of solid compounds to solid products in molten salt electrolytes has attracted widespread interest in metallurgy because it is simple, cost-effective, and environmentally friendly [1-3]. This technique has been applied to the reduction of various metal oxides such as $\mathrm{TiO}_{2}$ [4], $\mathrm{SiO}_{2}$ [5] $\mathrm{Ta}_{2} \mathrm{O}_{5}$ [6], $\mathrm{Fe}_{2} \mathrm{O}_{3}$ [7], $\mathrm{SnO}_{2}$ [8], $\mathrm{Tb}_{4} \mathrm{O}_{7}$ [9], $\mathrm{Nb}_{2} \mathrm{O}_{5}$ [10-12], $\mathrm{Cr}_{2} \mathrm{O}_{3}[13,14]$, and $\mathrm{CeO}_{2}$ [15]. Additionally, it has been employed to reduce spent oxide fuel (mainly consisting of $\mathrm{UO}_{2}$ ) to its metallic form in pyroprocessing technology for closed nuclear fuel cycles [1618]. Pyroprocessing is a high-temperature electrochemical fuel processing technology for recycling the spent oxide fuel from light water reactors into metal fuel for fast nuclear reactors. In the OR process for pyroprocessing, molten $\mathrm{LiCl}$ containing $\mathrm{Li}_{2} \mathrm{O}$ is generally used as the electrolyte for the reduction of the spent oxide fuel. The reduction products of the OR process are transferred to an integrated process, electrorefining, as feed materials. $\mathrm{U}, \mathrm{Pu}$, and other actinides are recovered by the electrorefining process in a $\mathrm{LiCl}-\mathrm{KCl}$ eutectic salt electrolyte at $500^{\circ} \mathrm{C}[19-26]$.
The electrode reactions in OR processes are well known $[16-18,27-32]$. The spent oxide fuels are used as cathodes by loading them into a permeable basket. The reactions at the cathode are as follows:

$$
\begin{aligned}
\mathrm{MO}_{2}+4 \mathrm{e}^{-} & \longrightarrow \mathrm{M}+2 \mathrm{O}^{2-} \text { (salt) } \\
\mathrm{Li}^{+} \text {(salt) }+\mathrm{e}^{-} & \longrightarrow \mathrm{Li} \text { (salt) } \\
\mathrm{MO}_{2}+4 \mathrm{Li} \text { (salt) } & \longrightarrow \mathrm{M}+4 \mathrm{Li}^{+} \text {(salt) }+2 \mathrm{O}^{2-} \text { (salt) }
\end{aligned}
$$

where $\mathrm{M}$ denotes actinides such as uranium and plutonium. Simultaneously, the main reaction at the Pt anode occurs as follows:

$$
2 \mathrm{O}^{2-} \longrightarrow \mathrm{O}_{2}(\mathrm{~g})+4 \mathrm{e}^{-}
$$

During electrolysis, the spent oxide fuel is reduced to metal and remains at the cathode. The $\mathrm{O}^{2-}$ ions produced at the cathode are then transported through the salt and discharged at the anode to form $\mathrm{O}_{2}$ gas.

In situ monitoring of the OR process enables efficient operation; its principle purpose is to monitor the performance and efficiency of a reduction cell. In particular, the 


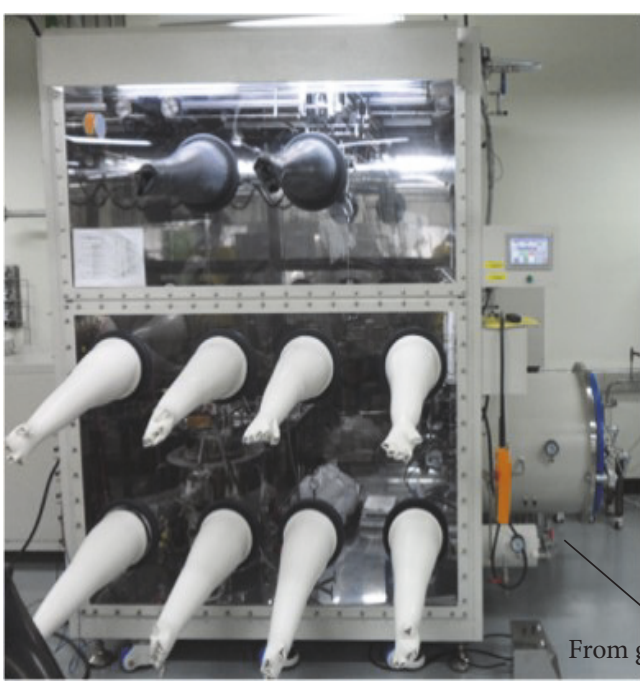

(a)

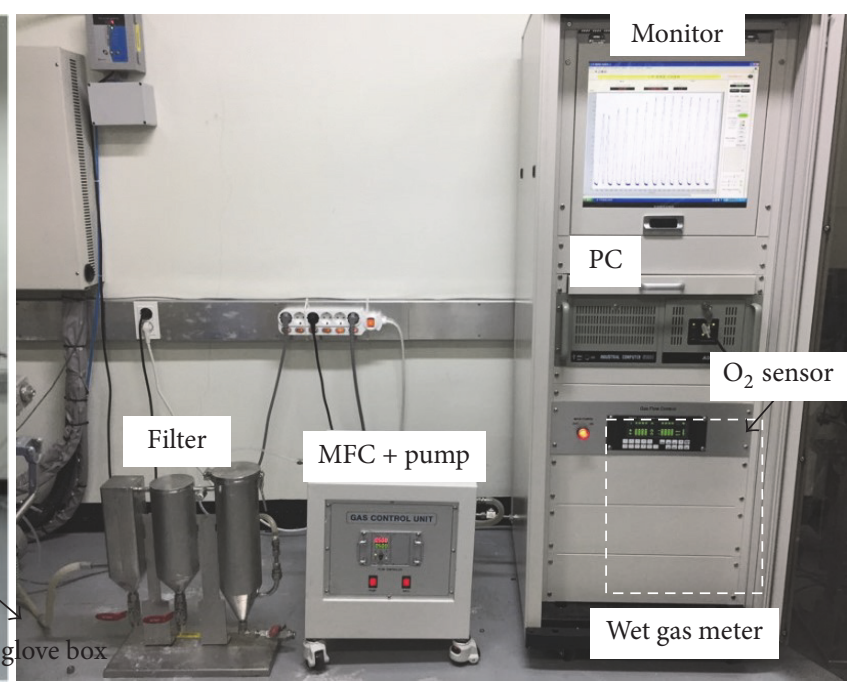

(b)

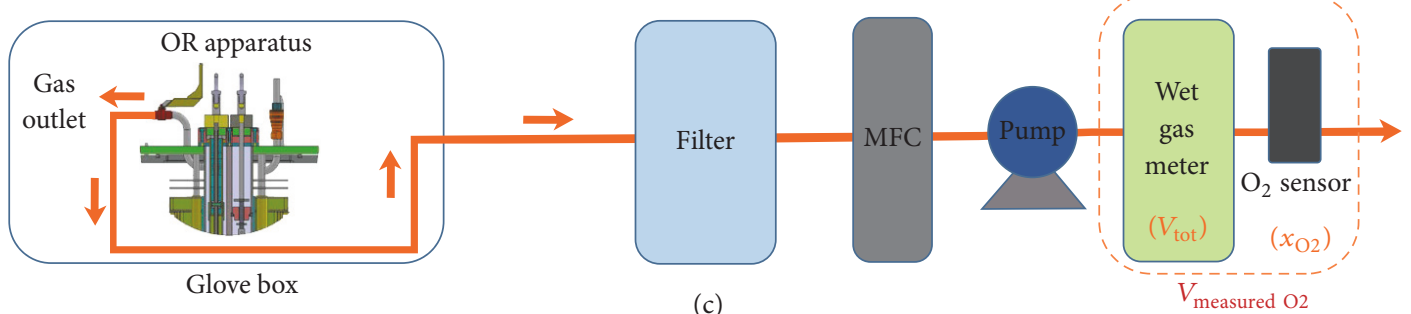

(c)

FIGURE 1: Setup for the present study: photographs of (a) Ar glove box equipped with the OR apparatus, (b) instrumentation for in situ measurement of $\mathrm{O}_{2}$ gas generated from the $\mathrm{Pt}$ anode during the OR process, and (c) schematic of the flow of $\mathrm{O}_{2}$ gas from the anode of the OR apparatus to the instrumentation.

extent to which the oxide fuel is converted to metal at the cathode is key information for determining the efficiency of a reduction cell. However, in situ monitoring of the reduction extent in real time has not been realized to date. Alternatively, the cumulative electrical charge applied to the oxide fuel $\left(Q_{\text {applied }}[\mathrm{C}]\right)$ which is obtained from the current $(I[\mathrm{~A}]=$ $\mathrm{Q} / t[\mathrm{C} / \mathrm{s}])$ and time $(t[\mathrm{~s}])$ during electrolysis is typically monitored. If the efficiency of the reduction cell is $100 \%$, then $Q_{a p p l i e d}$ is equal to the theoretical amount of electrical charge $\left(Q_{\text {theoretical }}\right)$ required to reduce all of the metal oxide to metal. However, since not all of $Q_{\text {applied }}$ is used to convert oxide to metal and the efficiency of the reduction cell is less than $100 \%$, the fraction of $Q_{\text {applied }}$ relative to $Q_{\text {theoretical }}$ is ambiguous. Here, we test the feasibility of quantitatively measuring $\mathrm{O}_{2}$ gas as a means of in situ monitoring of the OR process. The advantage of this approach is that it allows monitoring not of the applied quantity but of the produced quantity from OR reactions. For this study, the OR of $0.6 \mathrm{~kg}$ of simulated oxide fuel (simfuel) is performed in molten $\mathrm{Li}_{2} \mathrm{O}-\mathrm{LiCl}$ salt. The $\mathrm{O}_{2}$ gas produced at the anode is exhausted and quantitatively measured by means of in situ measurement instrumentation.

\section{Experimental Process}

The OR apparatus was used in a high-purity argon (Ar) atmosphere glove box (Figure 1(a)) where the concentrations of moisture and $\mathrm{O}_{2}$ were kept at below $1 \mathrm{ppm}$ and $10 \mathrm{ppm}$, respectively. Figure 2(a) shows a schematic drawing of the OR apparatus used in the present study. It consists of several components including a furnace (1) in Figure 2(a)), outer STS crucible (2) in Figure 2(a)), inner STS crucible (3) in Figure 2(a)), top flange (4) in Figure 2(a)), and electrodes (5), (6), and (7) in Figure 2(a)). The inner STS crucible $(165 \mathrm{~mm} \times$ $165 \mathrm{~mm} \times 250 \mathrm{~mm}$ ) was used to load the electrolyte. As the OR electrolyte, $5 \mathrm{~kg}$ of $1.5 \mathrm{wt} \%$ of $\mathrm{Li}_{2} \mathrm{O}$ (99.5\% purity, Alfa Aesar)-LiCl (99\% purity, Alfa Aesar) molten salt was used at $650^{\circ} \mathrm{C}$. LiCl was thermally dehydrated before use to remove moisture. The outer STS crucible aimed to protect the furnace in case of failure of the inner STS crucible. The top flange above the crucibles provided ports to suspend the electrodes and also prevented heat loss of the electrolyte.

The electrodes were electrically insulated from the top flange using a ceramic material at the contact area (8) in Figure 2(a)). The cathode (6) in Figure 2) was used by assembling the $\mathrm{Ni}$ conductor container and the rectangular basket $(75 \mathrm{~mm} \times 25 \mathrm{~mm} \times 204 \mathrm{~mm})$ made of three-ply layered (20325-100, Nichidai)-STS wire meshes. Porous simfuel pellets with a tap density of $3.59 \mathrm{~g} / \mathrm{cm}^{3}$ (density of single pellet of $6.89 \mathrm{~g} / \mathrm{cm}^{3}$, bulk density $62.86 \%$ ) and a cylindrical shape $(\phi 6.4 \times 6.2 \mathrm{~mm})$ were used by loading the STS wire mesh cathode basket. Its components and composition are listed in Table 1; it was composed of $\mathrm{UO}_{2}$, rare earth oxides, noble 


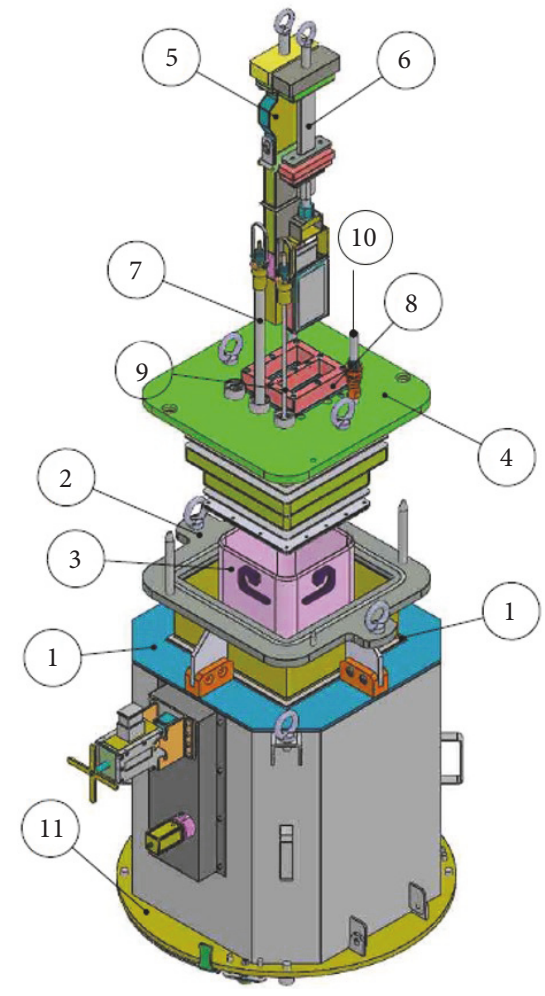

(a)

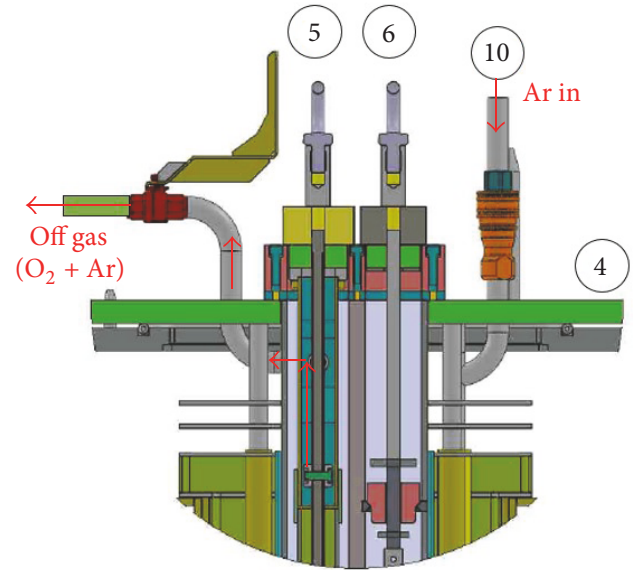

(b)

FIgURE 2: Schematic of the OR apparatus used for this study: (a) outer view (1): furnace, (2): outer STS crucible, (3): inner STS crucible, (4): top flange, (5): cathode, (6: anode, (7): reference electrode, (8): electrical insulator, (9): thermocouple, (10: Ar inlet, and (11): bottom) and (b) flow of incoming $\mathrm{Ar}$ and evolved gas $\left(\mathrm{Ar}+\mathrm{O}_{2}\right)$ through the top flange.

TABLE 1: Composition of the simfuel used in this study.

\begin{tabular}{lcc}
\hline Group & Surrogate oxides & $\begin{array}{c}\text { Compositions } \\
{[\text { wt.\%] }}\end{array}$ \\
\hline Actinide & $\mathrm{UO}_{2}$ or $\mathrm{UO}_{2.2}$ & 97.02 \\
\hline $\mathrm{Nd}_{2} \mathrm{O}_{3}$ & 0.70 \\
$\mathrm{CeO}_{2}$ & 0.44 \\
& $\mathrm{La}_{2} \mathrm{O}_{3}$ & 0.21 \\
Rare earths & $\mathrm{Pr}_{6} \mathrm{O}_{11}$ & 0.20 \\
& $\mathrm{Sm}_{2} \mathrm{O}_{3}$ & 0.14 \\
& $\mathrm{Y}_{2} \mathrm{O}_{3}$ & 0.08 \\
& $\mathrm{Gd}_{2} \mathrm{O}_{3}$ & 0.03 \\
\hline \multirow{3}{*}{ Salt-soluble fission products } & $\mathrm{BaO}$ & 0.31 \\
& $\mathrm{SrO}$ & 0.13 \\
Noble metals & $\mathrm{Eu}_{2} \mathrm{O}_{3}$ & 0.02 \\
\hline
\end{tabular}

metal oxides, and salt-soluble fission products. The simfuel was prepared by mixing of $\mathrm{UO}_{2}$ and surrogate powders, pelletizing, and sintering. The preparation conditions and methods for simfuel have been described elsewhere [33]. $\mathrm{Li}-\mathrm{Pb}$ alloy $(32 \mathrm{~mol} \% \mathrm{Li}$ ) in $\mathrm{MgO}$ served as the reference electrode (7) in Figure 2(a)). The anode module (5) in Figure 2(a)) consisted of a Pt anode and a shroud. A Pt plate
$(40 \mathrm{~mm} \times 3 \mathrm{~mm} \times 200 \mathrm{~mm})$ was used as the anode material. The anode shroud surrounds the $\mathrm{Pt}$ anode where $\mathrm{O}_{2}$ gas is generated; it forms chimneys that contain the $\mathrm{O}_{2}$ gas and form a pathway for its removal. The anode shroud used in this study consisted of a lower porous shroud for the salt phase and an upper nonporous shroud for the gas phase. Detailed descriptions of the anode and anode shroud have been reported in our previous study [34]. As shown in Figure 2(b), the evolved gas combination of $\mathrm{O}_{2}$ and Ar was continuously exhausted using a pump from the upper end of the shroud to the gas outlet; the gas was piped to in situ instrumentation installed outside the Ar glove box. The setup of the $\mathrm{O}_{2}$ gas monitoring instrumentation is presented in Figures 1(b) and 1(c). The instrumentation consisted of a mass flow controller (MFC), pump, wet gas meter, and sensor for $\mathrm{O}_{2}$ gas. The MFC (Line Tech, m3030v, Korea) was used to control the flow rate of the gas using the connected pump; it was given a set point of $1 \mathrm{~L} / \mathrm{min}$. The removal rate of $\mathrm{O}_{2}$ gas was set to be faster than the generation rate. As shown in Figure 2(b), Ar gas was allowed to flow into the top flange in order to constantly maintain the pressure inside of the OR apparatus. The wet gas meter (Shinakawa, W-NK 1B type, Japan) was employed to quantitatively measure the total volume $\left(V_{\text {tot }}\right)$ of the evolved gas (a combination of $\mathrm{O}_{2}$ and Ar gases) in real time. The volume of $\mathrm{O}_{2}\left(V_{\text {measured } \mathrm{O}_{2}}\right)$ was determined by multiplying $V_{\text {tot }}$ by the $\mathrm{O}_{2}$ concentration fraction $\left(x_{\mathrm{O}_{2}}\right)$ measured using 
an oxygen sensor (Advanced Micro Instruments, M65, US). $V_{\text {measured } \mathrm{O}_{2}}$ was monitored and recorded in real time using a computer. The $\mathrm{O}_{2}$ gas concentration in the Ar-filled glove box was carefully observed in order to determine whether $\mathrm{O}_{2}$ gas leaked out from the OR apparatus or the connected piping. Electrolysis was performed by applying a constant voltage between the cathode and $\mathrm{Pt}$ anode using an external power supply (Agilent Model 6671A). The potential between the cathode and the $\mathrm{Li}-\mathrm{Pb}$ reference electrode was monitored using a multimeter (Agilent, 34405A). After the OR process, the variation of $\mathrm{Li}_{2} \mathrm{O}$ concentration in the molten salt was checked using an autotitrator (G20, Mettler Toledo). A filter composed of a cylindrical polypropylene microfilter with a pore size of $1 \mu \mathrm{m}$ was used to protect the instrumentation from salt aerosols.

\section{Results and Discussion}

The constant-voltage electrolysis of $0.6 \mathrm{~kg}$ of simfuel was performed in $1.5 \mathrm{wt} . \% \mathrm{Li}_{2} \mathrm{O}-\mathrm{LiCl}$. A set of the obtained electrolysis data is presented in Figure 3; it includes the curves of the (a) cell voltage, (b) current, and (c) cathode potential. The constant voltage measured between the tops of the cathode and the anode was approximately $3.15 \mathrm{~V}$ owing to the IR drop, even though $3.35 \mathrm{~V}$ was applied by using the power supply (Figure $3(\mathrm{a})$ ). The constant-voltage interruption at appropriate intervals was conducted to prevent excessive formation of $\mathrm{Li}$ metal at the cathode. The presence of $\mathrm{Li}$ metal at the cathode could be observed through the potential between the cathode and $\mathrm{Li}-\mathrm{Pb}$ reference electrode at an open circuit potential (i.e., the $\mathrm{Li} / \mathrm{Li}^{+}$potential of about $-0.6 \mathrm{~V}$ ). While the constant voltage was applied, the cathode potential was lowered to about $-0.78 \mathrm{~V}$ (Figure 3(c)) because, as a cyclic voltammetry test in our previous study showed, $\mathrm{UO}_{2}$ is reduced at potentials more negative than $-0.6 \mathrm{~V}[30,31]$. A response current of about $40 \mathrm{~A}$ was passed by applying the constant voltage (Figure $3(\mathrm{~b})$ ). The averaged current density was $0.45 \mathrm{~A} / \mathrm{cm}^{2}$ for an effective anode surface area of $89.2 \mathrm{~cm}^{2}$ immersed in the $\mathrm{Li}_{2} \mathrm{O}-\mathrm{LiCl}$ salt. $Q_{\text {applied }}$ relative to $40 \%$ of $Q_{\text {theoretical }}$ was the applied charge to the simfuel during the $6.3 \mathrm{~h}$ electrolysis, which was not sufficient to completely reduce the simfuel. This incomplete electrolysis (low $Q_{\text {applied }}$ compared to $Q_{\text {theoretical }}$ ) was inevitable to monitor the $\mathrm{O}_{2}$ gas using the instrumentation without interruption during the daytime.

The evolved gas generated from the OR anode was continuously exhausted and monitored during the electrolysis. Figure 4 shows the cumulative measured volume of $\mathrm{O}_{2}$ gas $\left(V_{\text {measured } \mathrm{O}_{2}}\right)$ compared with the theoretically calculated volume of $\mathrm{O}_{2}$ gas $\left(V_{\text {thoretical }} \mathrm{O}_{2}\right.$ ) generated by the cumulative applied charge, $Q_{\text {applied }}$. $Q_{\text {applied }}$ was obtained from the current and time shown in Figure 3(b). The change in $Q_{\text {applied }}$ showed a step-like pattern; it repeatedly increased and then maintained a constant value because the current flowed during the voltage-on period and did not flow during the voltage-off period. $V_{\text {thoretical } \mathrm{O}_{2}}$ was calculated as follows:

$$
V_{\text {thoretical } \mathrm{O}_{2}}=\frac{Q_{\text {applied }}}{n F} \times 24.5 \text {, }
$$

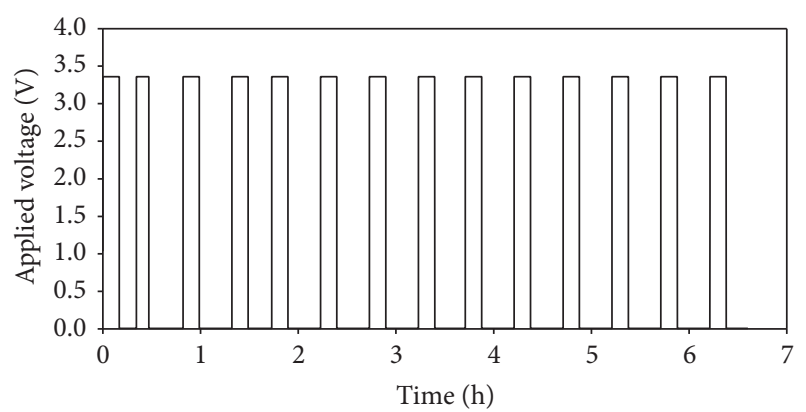

(a)

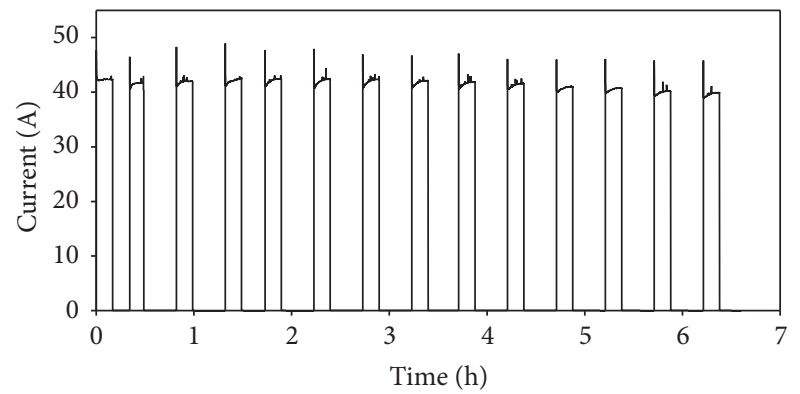

(b)

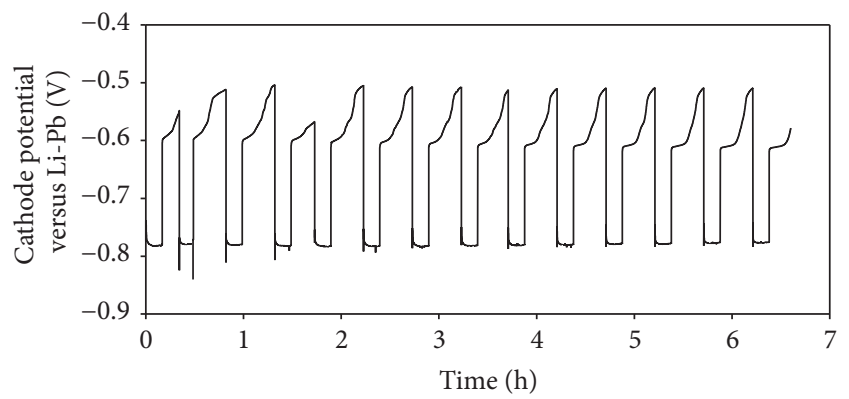

(c)

FIGURE 3: Electrolysis data: (a) applied voltage-time, (b) currenttime, and (c) cathode potential-time.

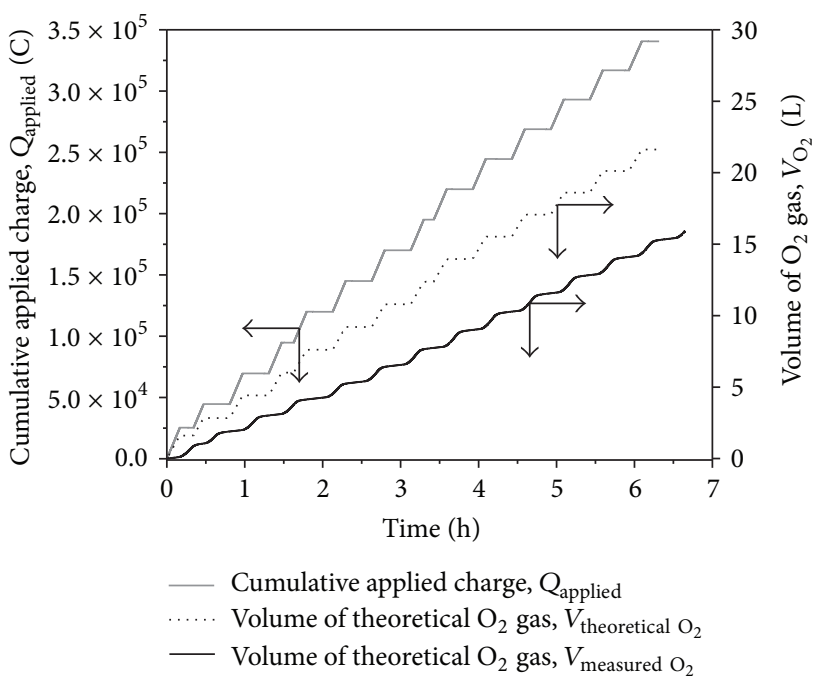

Figure 4: Comparison between the measured volume of $\mathrm{O}_{2}$ gas $\left(V_{\text {measured } \mathrm{O}_{2}}\right)$ and theoretically calculated volume of $\mathrm{O}_{2}$ gas $\left(V_{\text {thoretical }} \mathrm{O}_{2}\right)$ generated by the cumulative applied charge, $Q_{\text {applied }}$. 


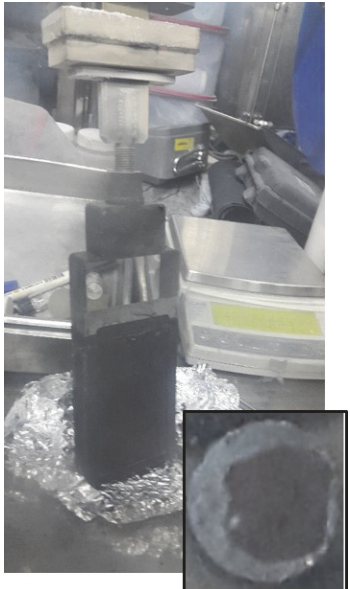

(a)

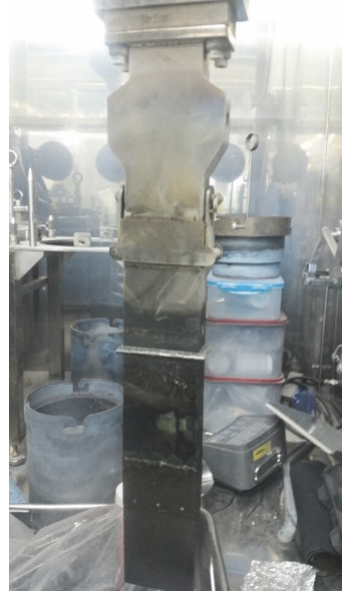

(b)

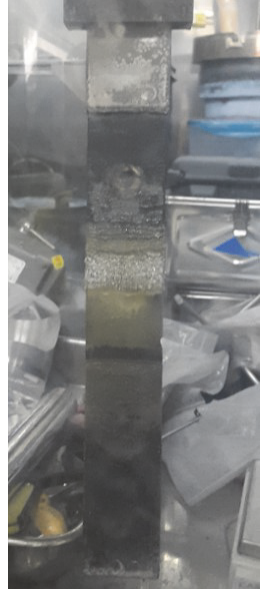

(c)

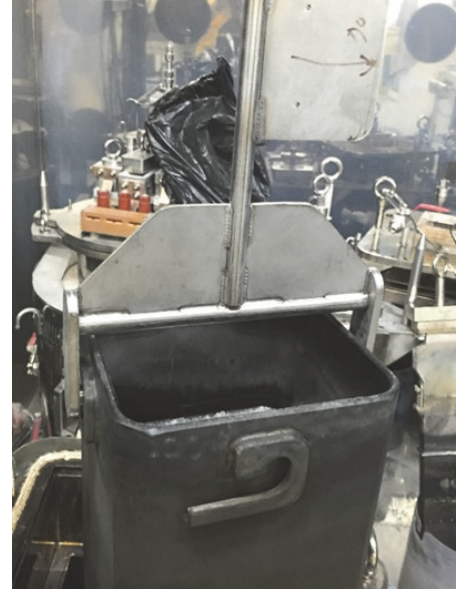

(d)

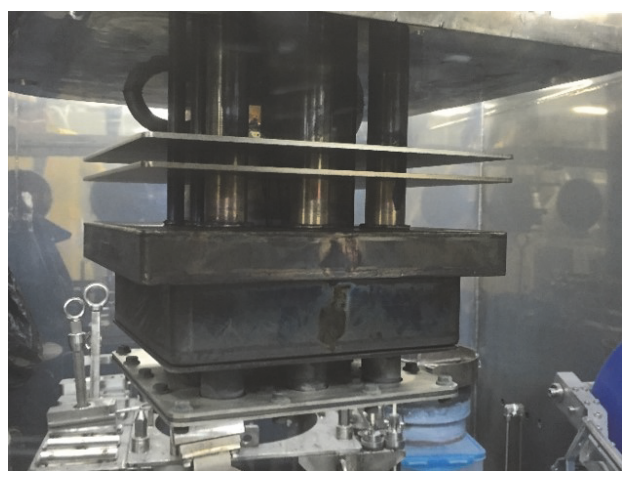

(e)

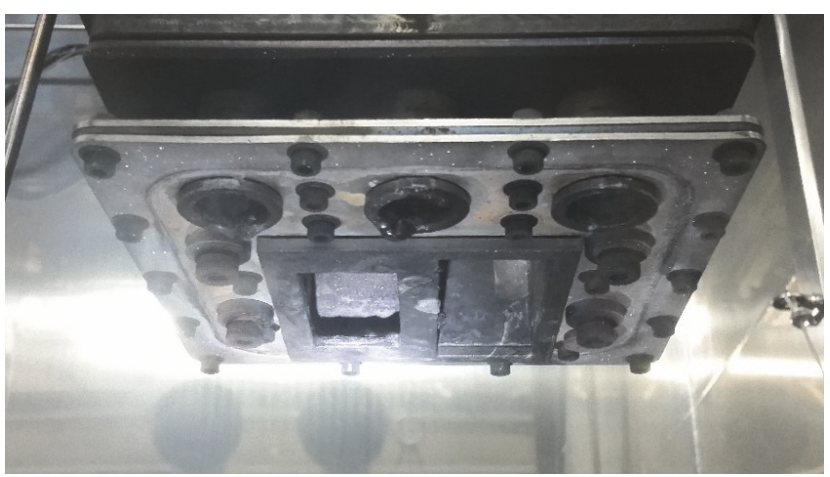

(f)

Figure 5: Photographs after electrolysis: (a) cathode (inset: reduction products); (b) anode shroud; (c) Pt anode and its electrical conductor; (d) inner crucible containing the salt; (e) side view of the top flange; and (f) bottom view of the top flange.

where $Q_{\text {applied }}$ is the electrical charge applied to the simfuel during electrolysis; $n$ is the number of electrons involved in the cathode reaction (1) (known to be four); $F$ is Faraday constant, $96,485 \mathrm{C} / \mathrm{mol} \mathrm{e}^{-}$; and 24.5 is the molar volume of ideal gas $(\mathrm{L} / \mathrm{mol})$ at $25^{\circ} \mathrm{C}$.

As expected, $V_{\text {thoretical }} \mathrm{O}_{2}$ increased in the same manner as $Q_{\text {applied }}$ because it was obtained using $Q_{\text {applied }}$ in (5). The change in $V_{\text {measured } \mathrm{O}_{2}}$ also showed a similar pattern to that of $V_{\text {thoretical } \mathrm{O}_{2}}$, which is evidence of successful production of $\mathrm{O}_{2}$ gas by the anode reaction (4). At the beginning of the electrolysis, $V_{\text {measured } \mathrm{O}_{2}}$ did not show a significant increase in spite of the increase in $Q_{\text {applied }}$; it increased after about $10 \mathrm{~min}$. This $10 \mathrm{~min}$ interval between $Q_{\text {applied }}$ and $V_{\text {measured } \mathrm{O}_{2}}$ was repeatedly observed during the electrolysis. This interval indicates the time needed for the $\mathrm{O}_{2}$ gas generated in the molten $\mathrm{Li}_{2} \mathrm{O}-\mathrm{LiCl}$ salt of the OR apparatus installed inside the Ar glove box to pass through the piping and to be measured in the instrument installed outside the glove box. It is notable that the difference between $V_{\text {thoretical } \mathrm{O}_{2}}$ and $V_{\text {measured } \mathrm{O}_{2}}$ gradually increased over the electrolysis period. At the end point of the electrolysis, $V_{\text {measured } \mathrm{O}_{2}}$ of $16 \mathrm{~L}$ was approximately $73 \%$ of $V_{\text {thoretical } \mathrm{O}_{2}}$ of $22 \mathrm{~L}$ that could theoretically be generated by the final value of the cumulative $Q_{\text {applied }}\left(3.4 \times 10^{5} \mathrm{C}\right)$. This result is reasonable given the fact that $Q_{\text {applied }}$ is not all used to convert the oxide fuel to metal owing to limited current efficiency. In our previous study [34], we conducted the OR process using simfuel under experimental conditions similar to those in the present study. We obtained the reduction product containing $U$ with the metal weight portion of $99 \%$ when the OR process with a current efficiency of $67 \%$ was conducted. This reliability was confirmed from the observation of the reduction product obtained from the OR run of this study. Some reduction products were randomly sampled from the top of the cathode basket; a cross-section of one of them is shown in the inset image of Figure 5(a). Its surface exhibits a metallic gray appearance unlike the original brown simfuel, which is also evidence of successful reduction during electrolysis. However, the unreduced region in the center of the crosssection remained because $Q_{\text {applied }}\left(40 \%\right.$ of $\left.Q_{\text {theoretical }}\right)$ was not enough for complete reduction. This inhomogeneity of the reduction over the region occurs because reduction of simfuel begins at the surface and progresses toward the center [29]. The concentration of $\mathrm{Li}_{2} \mathrm{O}$ (1.5 wt.\%) in $\mathrm{LiCl}$ measured through titration did not show a change before and after electrolysis, which means that the $\mathrm{O}_{2}$ gas measured using the instrumentation $\left(V_{\text {measured } \mathrm{O}_{2}}\right)$ was generated from the metal oxide in the simfuel. 
The electrolysis was also evaluated by visual inspection of the reduced simfuel pellets. After electrolysis, the electrodes were removed from the molten $\mathrm{Li}_{2} \mathrm{O}-\mathrm{LiCl}$ at $650^{\circ} \mathrm{C}$ and cooled to the ambient temperature. The used anode shroud (Figure 5(b)), Pt anode (Figure 5(c)), inner crucible (Figure 5(d)), and top flange (Figures 5(e) and 5(f)) were inspected. No severe corrosion or damage was observed, which indicates that the $\mathrm{O}_{2}$ gas was successfully discharged along the intended path without a leak in the OR apparatus and measured using the instrumentation.

\section{Conclusions}

The feasibility of quantitative measurement of the $\mathrm{O}_{2}$ gas generated from a Pt anode was tested to monitor the progress of the OR process. In situ measurement of $\mathrm{O}_{2}$ gas was performed using monitoring instrumentation during the $\mathrm{OR}$ of $0.6 \mathrm{~kg}$ of simfuel in molten $\mathrm{Li}_{2} \mathrm{O}-\mathrm{LiCl}$ salt. The measured cumulative volume of $\mathrm{O}_{2}$ gas $\left(V_{\text {measured }} \mathrm{O}_{2}\right)$ increased with the electrolysis time in a pattern similar to that of the cumulative applied charge, which implies successful monitoring of OR progress. The measured volume of the $\mathrm{O}_{2}$ gas using the applied electrical charge $\left(Q_{\text {applied }}\right)$ amounted to around $73 \%$ of the theoretical calculated volume $\left(V_{\text {thoretical }} \mathrm{O}_{2}\right)$ at the end point of the electrolysis. This OR progress was also confirmed by visual inspection of the reduced simfuel. This approach is advantageous because it allows the monitoring of not the applied quantity but the produced quantity from OR reactions. However, the leakage of $\mathrm{O}_{2}$ gas in the instrumentation should be carefully avoided for its successful monitoring.

\section{Conflicts of Interest}

The authors declare that they have no conflicts of interest.

\section{Acknowledgments}

This study was supported by the National Research Foundation of Korea (NRF) of the Korean Government (MISP) [Grant no. 2017M2A8A5015077].

\section{References}

[1] D. Wang, X. Jin, and G. Z. Chen, "Solid state reactions: an electrochemical approach in molten salts," Annual Reports Section "C" (Physical Chemistry), vol. 104, pp. 189-234, 2008.

[2] A. M. Abdelkader, K. T. Kilby, A. Cox, and D. J. Fray, "DC voltammetry of electro-deoxidation of solid oxides," Chemical Reviews, vol. 113, no. 5, pp. 2863-2886, 2013.

[3] W. Xiao and D. Wang, "The electrochemical reduction processes of solid compounds in high temperature molten salts," Chemical Society Reviews, vol. 43, no. 10, pp. 3215-3228, 2014.

[4] G. Z. Chen, D. J. Fray, and T. W. Farthing, "Direct electrochemical reduction of titanium dioxide to titanium in molten calcium chloride," Nature, vol. 407, no. 6802, pp. 361-364, 2000.

[5] K. Yasuda, T. Nohira, R. Hagiwara, and Y. H. Ogata, "Direct electrolytic reduction of solid $\mathrm{SiO} 2$ in molten $\mathrm{CaCl} 2$ for the production of solar grade silicon," Electrochimica Acta, vol. 53, no. 1, pp. 106-110, 2007.
[6] S. M. Jeong, J.-Y. Jung, C.-S. Seo, and S.-W. Park, "Characteristics of an electrochemical reduction of $\mathrm{Ta} 2 \mathrm{O} 5$ for the preparation of metallic tantalum in a LiCl-Li2O molten salt," Journal of Alloys and Compounds, vol. 440, no. 1-2, pp. 210-215, 2007.

[7] S. I. Wang, G. M. Haarberg, and E. Kvalheim, "Electrochemical behavior of dissolved $\mathrm{Fe}_{2} \mathrm{O}_{3}$ in molten $\mathrm{CaCl}_{2}-\mathrm{KF}$," Journal of Iron and Steel Research International, vol. 15, no. 6, pp. 48-51, 2008.

[8] M. Gibilaro, J. Pivato, L. Cassayre, L. Massot, P. Chamelot, and P. Taxil, "Direct electroreduction of oxides in molten fluoride salts," Electrochimica Acta, vol. 56, no. 15, pp. 5410-5415, 2011.

[9] D. Wang, G. Qiu, X. Jin, X. Hu, and G. Z. Chen, "Electrochemical metallization of solid terbium oxide," Angewandte Chemie International Edition, vol. 45, no. 15, pp. 2384-2388, 2006.

[10] X. Y. Yan and D. J. Fray, "Production of niobium powder by direct electrochemical reduction of solid $\mathrm{Nb}_{2} \mathrm{O}_{5}$ in a eutectic $\mathrm{CaCl}_{2}-\mathrm{NaCl}$ melt," Metallurgical and Materials Transactions $\mathrm{B}$, vol. 33, no. 5, pp. 685-693, 2002.

[11] Q. Xu, L.-Q. Deng, Y. Wu, and T. Ma, "A study of cathode improvement for electro-deoxidation of $\mathrm{Nb} 2 \mathrm{O} 5$ in a eutectic $\mathrm{CaCl} 2-\mathrm{NaCl}$ melt at $1073 \mathrm{~K}$," Journal of Alloys and Compounds, vol. 396, no. 1-2, pp. 288-294, 2005.

[12] S. M. Jeong, H. Y. Yoo, J.-M. Hur, and C.-S. Seo, "Preparation of metallic niobium from niobium pentoxide by an indirect electrochemical reduction in a LiCl-Li2O molten salt," Journal of Alloys and Compounds, vol. 452, no. 1, pp. 27-31, 2008.

[13] G. Z. Chen, E. Gordo, and D. J. Fray, "Direct electrolytic preparation of chromium powder," Metallurgical and Materials Transactions B, vol. 35, no. 2, pp. 223-233, 2004.

[14] E. Gordo, G. Z. Chen, and D. J. Fray, "Toward optimisation of electrolytic reduction of solid chromium oxide to chromium powder in molten chloride salts," Electrochimica Acta, vol. 49, no. 13, pp. 2195-2208, 2004.

[15] B. Claux, J. Serp, and J. Fouletier, "Electrochemical reduction of cerium oxide into metal," Electrochimica Acta, vol. 56, no. 7, pp. 2771-2780, 2011.

[16] L. I. Redey and K. Gourishankar, "Direct electrochemical reduction of metal-oxides," US Patent 6540902B1.

[17] S. D. Herrmann, S. X. Li, M. F. Simpson, and S. Phongikaroon, "Electrolytic reduction of spent nuclear oxide fuel as part of an integral process to separate and recover actinides from fission products," Separation Science and Technology, vol. 41, no. 10, pp. 1965-1983, 2006.

[18] S. Herrmann, S. Li, and M. Simpson, "Electrolytic reduction of spent light water reactor fuel bench-scale experiment results," Journal of Nuclear Science and Technology, vol. 44, no. 3, pp. 361367, 2007.

[19] J. J. Laidler, J. E. Battles, W. E. Miller, J. P. Ackerman, and E. L. Carls, "Development of pyroprocessing technology," Progress in Nuclear Energy, vol. 31, no. 1-2, pp. 131-140, 1997.

[20] J. P. Ackerman, T. R. Johnson, L. S. H. Chow, E. L. Carls, W. H. Hannum, and J. J. Laidler, "Treatment of wastes in the ifr fuel cycle," Progress in Nuclear Energy, vol. 31, no. 1-2, pp. 141-154, 1997.

[21] R. W. Benedict and H. F. McFarlane, "EBR-II spent fuel treatment demonstration project status," Radwaste Magazine, vol. 5, p. 23, 1998.

[22] T. Inoue and L. Koch, "Development of pyroprocessing and its future direction," Nuclear Engineering and Technology, vol. 40, no. 3, pp. 183-190, 2008. 
[23] T. Inoue, T. Koyama, and Y. Arai, "State of the art of pyroprocessing technology in Japan," in Proceedings of the 2nd International Conference on Asian Nuclear Prospects, ANUP 2010, pp. 405413, ind, October 2010.

[24] K. M. Goff, J. C. Wass, K. C. Marsden, and G. M. Teske, "Electrochemical processing of used nuclear fuel," Nuclear Engineering and Technology, vol. 43, no. 4, pp. 335-342, 2011.

[25] K. Nagarajan, B. Prabhakara Reddy, S. Ghosh et al., "Development of pyrochemical reprocessing for spent metal fuels," in Proceedings of the 2nd International Conference on Asian Nuclear Prospects, ANUP 2010, pp. 431-436, ind, October 2010.

[26] T. Koyama, Y. Sakamura, M. Iizuka, T. Kato, T. Murakami, and J.-P. Glatz, "Development of pyro-processing fuel cycle technology for closing actinide cycle," Procedia Chemistry, vol. 7, pp. 772-778, 2012.

[27] E.-Y. Choi and S. M. Jeong, "Electrochemical processing of spent nuclear fuels: An overview of oxide reduction in pyroprocessing technology," Progress in Natural Science: Materials International, vol. 25, no. 6, pp. 572-582, 2015.

[28] Y. Sakamura, M. Kurata, and T. Inoue, "Electrochemical reduction of $\mathrm{U} \mathrm{O} 2$ in molten $\mathrm{Ca} \mathrm{Cl} 2$ or LiCl," Journal of the Electrochemical Society, vol. 153, no. 3, pp. D31-D39, 2006.

[29] Y. Sakamura, T. Omori, and T. Inoue, "Application of electrochemical reduction to produce metal fuel material from actinide oxides," Nuclear Technology, vol. 162, no. 2, pp. 169-178, 2008.

[30] S. M. Jeong, H.-S. Shin, S.-H. Cho, J.-M. Hur, and H. S. Lee, "Electrochemical behavior of a platinum anode for reduction of uranium oxide in a $\mathrm{LiCl}$ molten salt," Electrochimica Acta, vol. 54, no. 26, pp. 6335-6340, 2009.

[31] S. M. Jeong, H.-S. Shin, S.-S. Hong, J.-M. Hur, J. B. Do, and H. S. Lee, "Electrochemical reduction behavior of U3O8 powder in a LiCl molten salt," Electrochimica Acta, vol. 55, no. 5, pp. 1749$1755,2010$.

[32] J.-M. Hur, S. M. Jeong, and H. Lee, "Underpotential deposition of $\mathrm{Li}$ in a molten LiCl-Li2O electrolyte for the electrochemical reduction of U from uranium oxides," Electrochemistry Communications, vol. 12, no. 5, pp. 706-709, 2010.

[33] S.-C. Jeon, K.-Y. Lee, J.-W. Lee, Y.-Z. Cho, and D.-H. Ahn, "Scaling up and tailoring the fabrication of $\mathrm{UO}_{2}$ porous pellet with a simulated spent fuel composition," in Proceedings of the International Pyroprocessing Research Conference, Jeju Island, Korea, 2016.

[34] E. Choi, J. Lee, D. H. Heo et al., "Electrolytic reduction runs of $0.6 \mathrm{~kg}$ scale-simulated oxide fuel in a $\mathrm{Li}_{2} \mathrm{O}-\mathrm{LiCl}$ molten salt using metal anode shrouds," Journal of Nuclear Materials, vol. 489, pp. 1-8, 2017. 


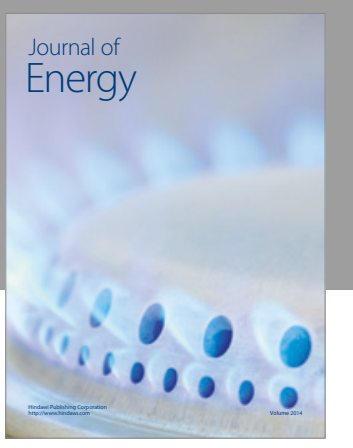

Journal of

Industrial Engineering
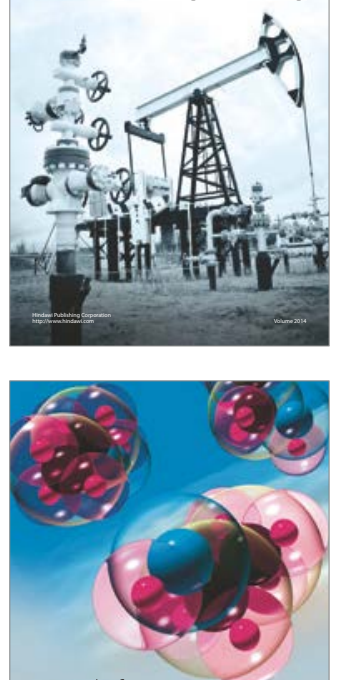

Fuels
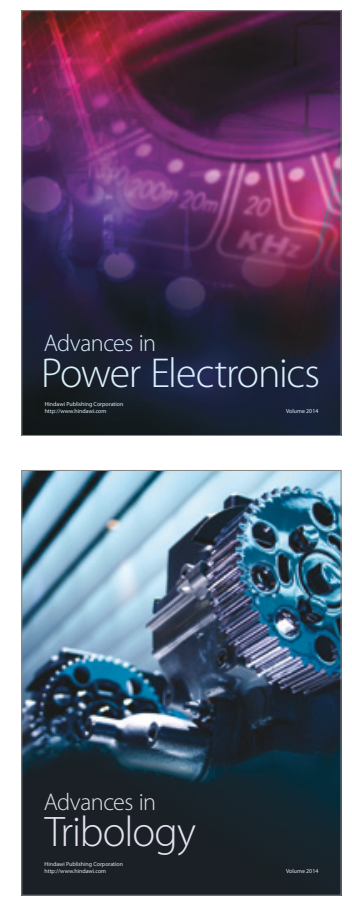
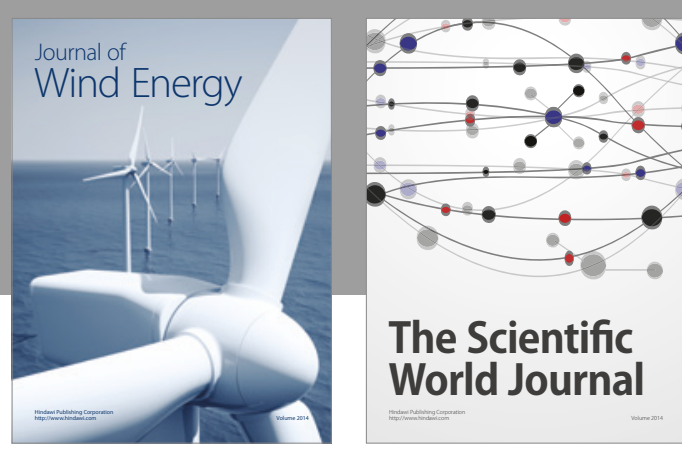

The Scientific World Journal
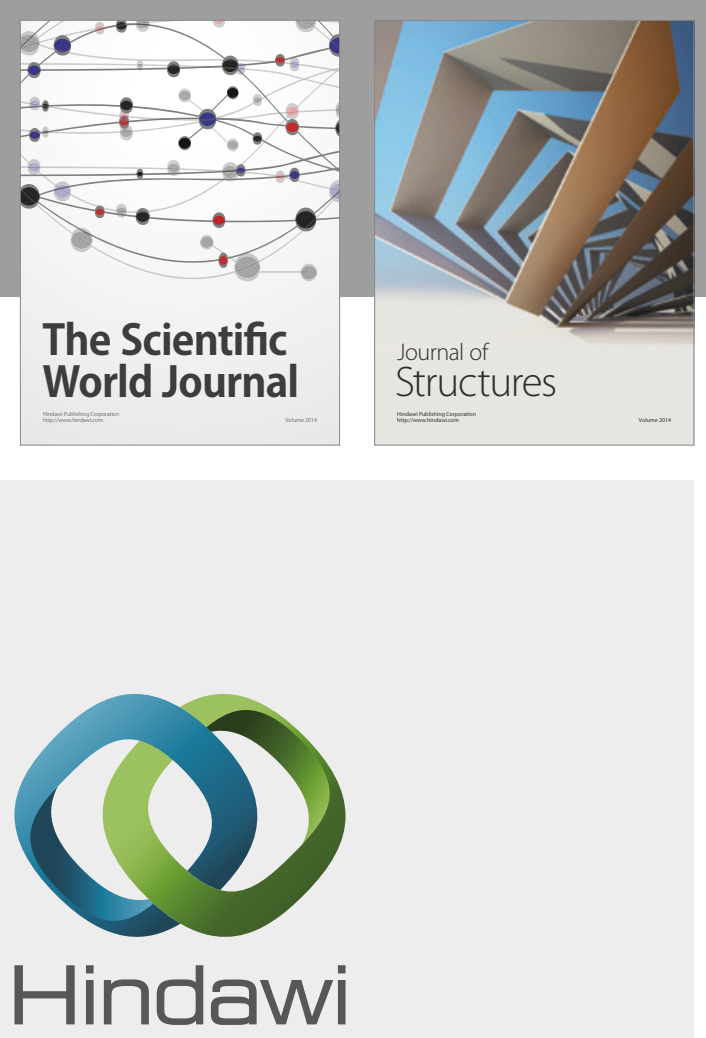

Submit your manuscripts at

https://www.hindawi.com
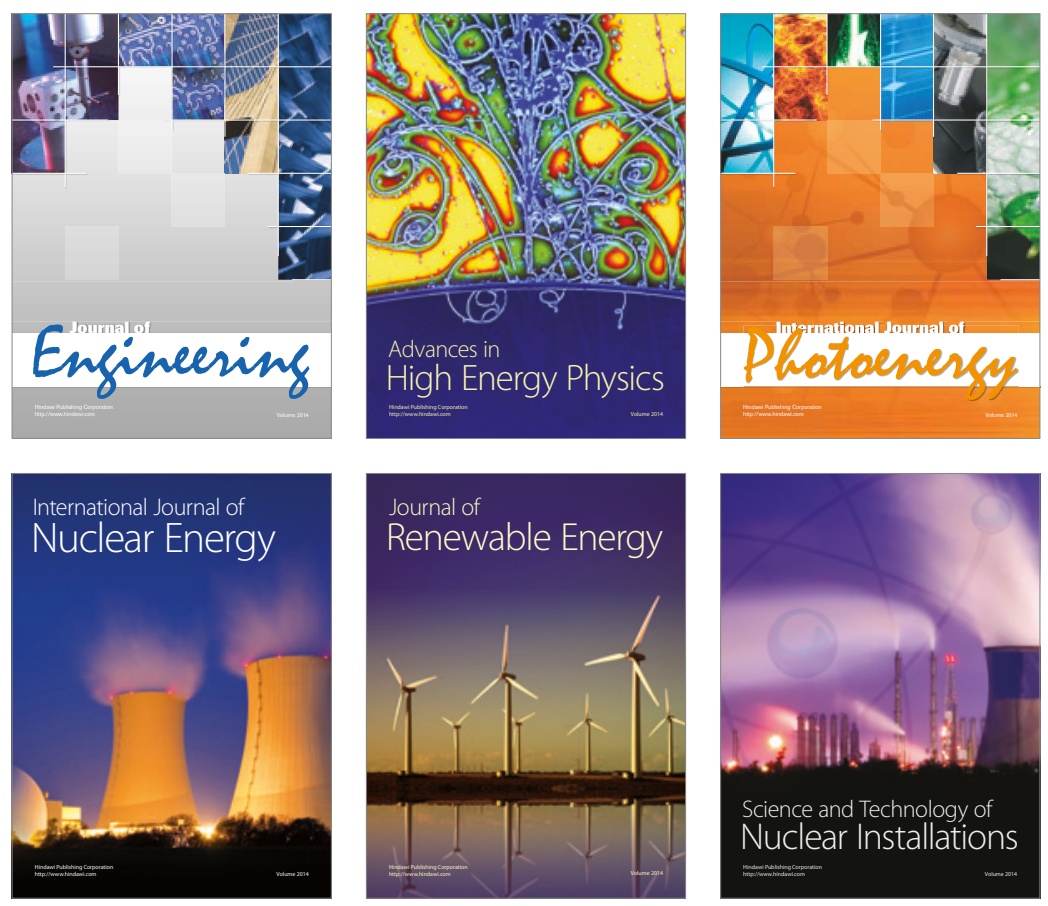

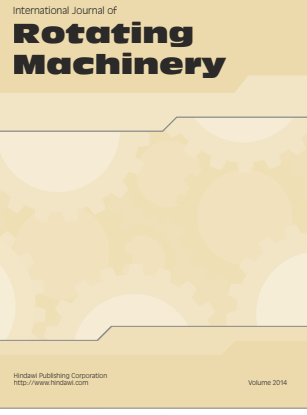

Journal of

Petroleum Engineering

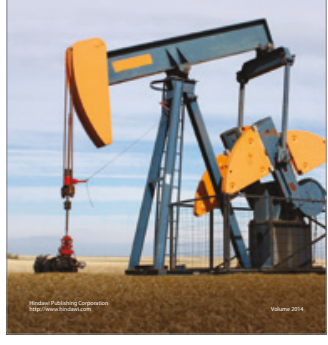

Journal of
Solar Energy
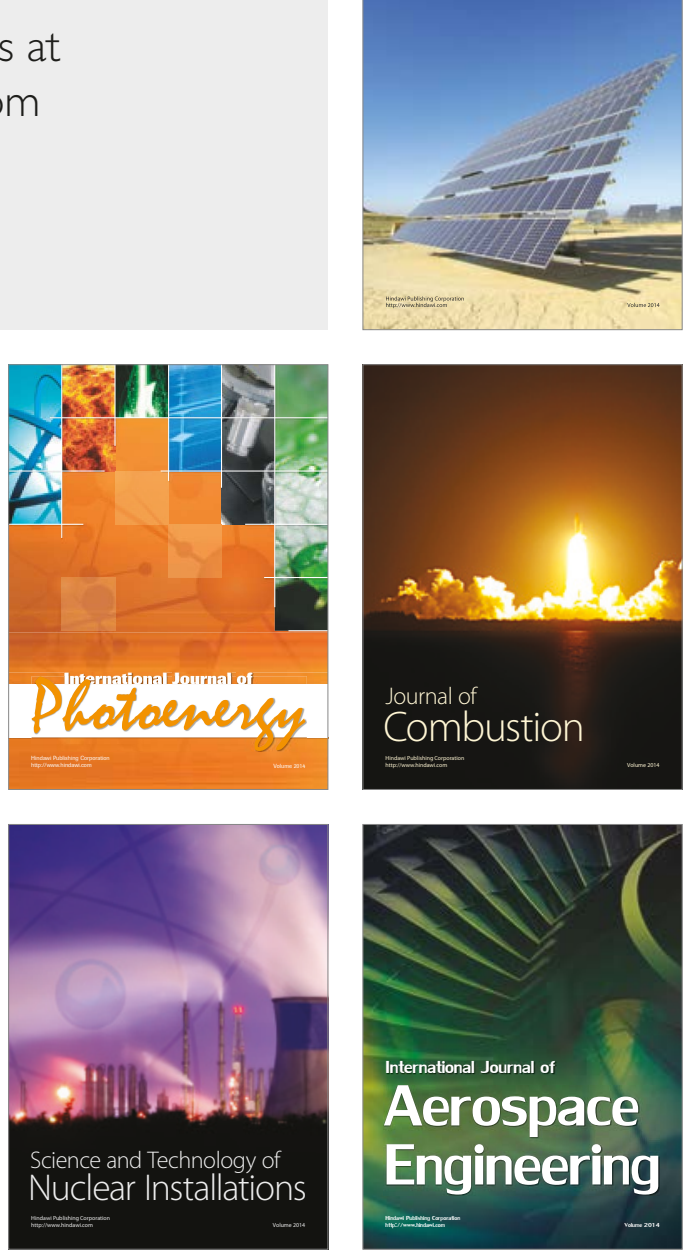